Agro-Science Journal of Tropical Agriculture, Food, Environment and Extension Volume 12 Number 2 May 2013 pp. 1- 9

ISSN 1119-7455

\title{
DETERMINANTS OF AGRICULTURAL MICRO-CREDIT REPAYMENT- EVIDENCE FROM MINNA MICROFINANCE BANK, NIGERIA
}

\author{
${ }^{1}$ Coker, A. A. and ${ }^{1}$ Kure, A. M. \\ ${ }^{1}$ Department of Agricultural Economics and Extension Technology, School of Agriculture \\ and Agricultural Technology, Federal University of Technology, Minna, P.M.B. 65, Minna, \\ Nigeria.
}

\begin{abstract}
The study assessed the determinants of agricultural micro-credit repayments by beneficiaries of Minna Micro-finance Bank, Nigeria. Multi-stage sampling technique was employed to select 180 respondents for the study while descriptive statistics and multinomial binary logit model were employed for data analyses. The study affirmed that substantial proportion of respondents (42.78\%) were smallholders owning between 1.1-2.0 hectares of land. Ironically, 61.67\% do not belong to cooperatives or farmers' associations. The volume of loans disbursed to beneficiaries was a significant determinant of agricultural micro-credit repayment. The analysis further established that repayment increased with the volume of micro-credit received, as $100 \%$ and $82 \%$ of those who received above $\$ 250,000$ and $\$ 200,000$ - $\$ 250,000$, respectively repaid compared to $74.34 \%$ of those who received between $\$ 50,000$ and $\$ 100,000$. Also, majority (68.89\%) of the respondents indicated that the short period of loan tenor, high interest rate (55\%) and loan period (54\%) were major obstacles in loan acquisition. Against this backdrop, the study recommended the need for proper financial analysis of beneficiaries' enterprises with the view to effectively ascertaining the quantum of credit needs while premising financial inflow of the bank on long term funds (without prejudice to the existing revolving loan mechanism) such as the pension contributions, with the view to enhancing the resource base of the bank and its ability to effectively support beneficiaries while guaranteeing its own sustainability. Channeling micro-credits through farmer institutions, allowing for longer loan repayment periods and premising interest on economic and social considerations will also enhance effective loan recovery.
\end{abstract}

Keywords: Agricultural micro-credit repayment, volume of micro-credit, financial analysis, long term funds, cooperatives.

\section{INTRODUCTION}

Over the past decades, the contributions of agriculture to Nigeria's economy has continued to decline; from over $50 \%$ of the GDP in the $60 \mathrm{~s}$ to $23 \%$ as at 2014 , given the dwindling role of the sector on one hand and the simultaneous expansion of the other sectors of the economy, particularly, the service sector. Aside this, agriculture has not been able to meet with its other traditional roles such as provision of food for the generality of the populace, raw materials supply, foreign exchange earnings and provision of gainful employment (Olatunji, 2010). Agricultural micro-credit has been a key missing link given the resource poor nature of the Nigerian farmers. To redress the situation, several projects and programmes were initiated by successive governments including the on- going Agricultural Transformation Agenda under policy measures. Most of these initiatives provided for a credit component to meet the financial needs of the resource poor farmers. Some of these interventions include the National Acceleration Food Production Programme (NAFPP), Agricultural Development Programmes (ADPs), Green Revolution (GR), and River Basin Development Authority (RBDA), Directorate for Food, Roads and Rural Infrastructure (DFFRI) (Aku, 1981), the Rural Finance Institutions Building Programme, the Nigeria Incentive-based Risk Sharing for Agricultural Lending (NIRSAL) which is pushing a simultaneous implementation and alignment of the commodity value chains with the financial value chain. The recognition that 
agricultural credit is crucial to the development of the farming sector made the Federal Government to adopt several subtle and overt measures to encourage the flow of bank credit to farmers, beginning with the 1972 fiscal year. In this direction, the Central Bank of Nigeria (CBN) used credit guidelines to prescribe the size of credit allocation by Banks to preferred sectors of the economy including agriculture (Nnanna, 2011). In most developing countries, including Nigeria, credit is the pivot on which agricultural development rest and is always used as yardstick to stimulate agricultural development in the desired direction. It is thus only logical at this juncture to stress that the key roles agriculture plays in Nigeria's economy and the structure of production wherein the smallholder dominates, producing over $70 \%$ of total agricultural output, demands intensive financial intervention given the resource poor nature of most small-holder farmers. However, despite the general acceptance of the relevant roles of credit and wide appreciation by most governments of the need for credit, credit schemes for households and agriculture unfortunately, have failed at various times to yield the expected result. Where the schemes have survived, they had hardly made significant improvements on the status of the loan beneficiaries. Ajah, et al (2013) observed that credit administration in many parts of Nigeria has not been impressive when placed against their repayment performance. Ogundele et al., (2009) on the other hand attributed the low impact of credit schemes to the small volumes of loans. Lack of credit is generally seen as one of the main reasons why many people in developing economies remain poor. Usually, the poor have no access to loans from the banking system given the difficulties in putting up acceptable collaterals, high administrative charges (Hermes and Lensink, 2004 and Awoke, 2004).

The CBN has been involved in various interventions to improve access to needed finance for development. One of such scheme is the Agricultural Credit Guarantee Scheme Fund (ACGSF). For instance, a total of 1,330 small farmers loans valued at \$66.5million were guaranteed between January and August, 2005 in Niger State. In terms of loan repayment, a total of 1,047 loans, valued $\$ 59.96$ million from previous loans guaranteed under the scheme were fully repaid during the same period (CBN, 2007). As at the close of 2005, loans to 36,584 farmers, valued at $\$ 534.50$ million had been guaranteed under the scheme since 1978. In cumulative terms, the number and value of loans repaid by the beneficiaries in Niger State stood at 32,818 loans, (i.e. $89.71 \%$ of total loans granted in the State), valued at 37,575 million $(70.30 \%)$. The State ranked first in terms of the total number and second in terms of valued of loans guaranteed across the country (Umar, 2005).

Thus, the shift from community banking to micro-finance banking in Nigeria was aimed at strengthening the sustainable basic empowerment of the active poor and economically weak citizens. The Central Bank's guidelines on Microfinance Banks of 2009 provided the backing for the implementation of this policy in all the twenty four (25) Local Government Areas in the State.

Inadequate finance has been a major constraint to increasing food production and the modernization of agriculture in Nigeria, given that credit is an important catalyst for agricultural development. Today, the limited access to credit facilities by farmers, particularly, the small-scale farmers is said to be responsible for the low productivity of the agriculture sector (Tunde, 2009).

Though, the tiers of government have made effort towards improving productivity of Nigeria's agriculture by providing credits to farmers, these attempts have not yielded meaningful result. Researchers have attributed the failures of many government credit programmes to high rate of non-repayment of agricultural loans. These researchers point to failure of lender agencies in playing their roles in loan recovery process as a major central contributor to agricultural loan default. Most credit institutions in Nigeria are also faced with a lot of repayment problems, because credit policies are made without proper analysis of borrowers, farming operations and repayment potentials (Oshuntogun, 2007). This development demands a review of the determinants of credit repayment in the study area. The broad objective of the study was to assess the determinants of agricultural micro-credit repayments by beneficiaries of Minna Micro-finance Bank. The specific objectives were to: (i) describe the socioeconomic characteristics of micro-credit beneficiaries under the Minna Micro-finance Bank; (ii) ascertain the volume of loan applications, receipts and repayments by respondents; (iii) ascertain the determinants of microcredit repayment among beneficiaries of Minna Micro-finance Bank; and (iv) examine the challenges encountered by respondents in repaying micro-credits obtained from Minna Micro-finance Bank.

This study is important given that it will determine how far-off the objectives of micro-credit repayments have been achieved in Minna Microfinance Bank. In a depressing economy like Nigeria, where several banks and other financial intermediaries have collapsed, many more insolvent, credit control and loan recovery remain a livewire for survival in the money and capital markets. In general terms, adequate loan 
repayments and effective credit recovery is a function of an ideal credit appraisal, credit disbursement, control and management system (Oyo, 2012). Most importantly, empirical evidence as to what factors determine loan repayment and loan recovery are seldom in Niger State and is yet to be undertaken in Minna Micro-finance Bank, this study has become imperative and will take a step to determine the factors that affect loan repayments with a view to providing necessary information needed to bridge the knowledge gap.

\section{MATERIALS AND METHODS Area of the Study}

The study was conducted in Chanchaga Local Government Area of Niger State, Nigeria. The State was created in 1976 out of the then NorthWestern State. It lies between Latitude $8^{0} 21^{\prime} \mathrm{N}$ and $11^{\circ} 30^{\prime} \mathrm{N}$ and Longitude $330^{\prime} \mathrm{E}$ and $7^{\circ} 20^{\prime} \mathrm{E}$ in the North Central Geographical Zone of Nigeria. The State is bordered to the North by Zamfara State to the North-east by Kebbi, to the South by Kogi State, to the South-west by Kwara State while Kaduna State and Federal Capital Territory border the State to the North-east. The State lies in the central Niger Basin. The most prominent features of the State are Rivers Niger and Kaduna which traverse the State in West-east and Northsouth direction respectively. It has a moderate tropical continental climate. The main features of which are two distinct and pronounced seasons of dry and wet seasons with rainfall concentrated in the wet season which extends between 5-6 months of the year and a steady high temperature. The State has a population of 3,950,249 (National Population Commission, 2006) made up of the three major ethnic groups of Nupe, Gbagyi, and Hausa with over 10 minor ethnic groups, comprising Kamuku, Kambari, Koro, Kadara, Dibbo, Baruba, Ungwai and Pangu, amongst others. The State is made up of twenty five Local Government Drear and divided into three Agricultural Zones, namely Zone 1, Zone II, and Zone 111.

\section{Sampling Technique}

The study covers Chanchaga Local Government Area of Niger State where the beneficiaries of the Minna Microfinance Bank are concentrated. The multi-stage sampling technique was employed for this study. The first stage was the purposive selection of Chanchaga Local Government Area given that most beneficiaries are concentrated in the area. The second stage involved the selection of 6 out of the 11 benefiting wards, using simple random sampling technique, while the third stage entailed the selection of 180 respondents from a frame of 1,000 beneficiaries (Table1.) using the sample size calculator at $5 \%$ precision level and $95 \%$ confidence level. The following research hypotheses were tested under the study:

Ho: There are no significant relationships between the determinants of micro-credit repayment and micro-credit repayment.

Ha: There are significant relationships between the determinants of micro-credit repayment and microcredit repayment.

\section{Method of Data Collection}

Primary and secondary data were used for the study. The secondary data were obtained from the records of Minna Microfinance Bank Limited while the primary data were obtained from respondents through structured questionnaire and oral interviews. Two types of questionnaires were administered, with a view to collecting relevant information from the Bank officials and the loan beneficiaries.

\section{Data Analysis}

Simple descriptive statistics such as mean, frequency distribution, percentages were used to achieve objectives 1,2 , and 4 of this study. Multinomial Logistic Model was used. The model is appropriate when individuals can choose only one outcome from among the set of mutually exclusive, collectively exhaustive alternatives. The choice of the method was based on the fact that the level of loan repayment (dependent variable) is a categorical variable which can take three (3) levels of classification namely (i) Beneficiary who have fully repaid their loans on what was due;(ii) Beneficiaries who have paid part of what was due; and (iii) Beneficiaries who are yet to pay their due microcredit. In the multinomial Logit model, the dependent variable takes the value of 0,1 , and 2 . The probability that the respondents belong to the repayment group reduces to:

$$
P_{i j}=\frac{e \beta_{j} x i}{1+\sum_{k=1} e \beta} \ldots \ldots \ldots \ldots \ldots . .(1)
$$

The generalized multinomial model is expressed as

$$
P_{i j}=\frac{e \beta_{j} x_{i}}{1+\sum_{k=0}^{j} e_{k}^{\beta} \times_{i}}
$$

while the probability of being in the base outcome group is

$$
P_{i o}=\frac{1}{1+\sum_{k=0}^{3} e_{k}^{\beta} \times_{i}}
$$


Determinants of Agricultural Micro-Credit Repayment-

Where $\mathrm{I}=1,2 \ldots \mathrm{n}$ variables $\mathrm{k}=0,1 . . \mathrm{j}$ groups and $\mathrm{B}$ $=\mathrm{a}$ vector of parameters that relates $\mathrm{X}$ to the probability of being in group $\mathrm{j}$, where there are $\mathrm{j}+1$ groups. The various independent variables included in the final model are as follows:

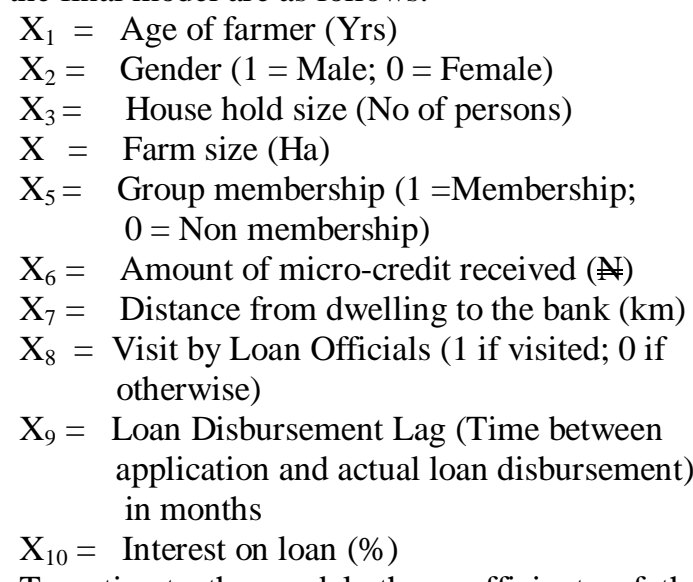

To estimate the model, the coefficients of the base outcome are normalized to zero (0). This is because the probabilities for all the choices must sum up to the unity. Hence, for 3 choices, only (3-1) distinct sets of parameters can be identified and estimated. The natural logarithms of the old ratio of equations (1) and (2) give the estimating equation as:

$$
n P_{i j}=\frac{\beta_{i} X_{i}}{P_{i 0}}
$$

This denotes the relative probability of each of the other groups to the probability of the base outcome. The estimated coefficients for each choice therefore reflect the effects of $\mathrm{Xi}$ on the likelihood of the farmers choosing that alternative relative to the base outcome. The estimation was done using STATA statistical analytical software. The final estimates were selected based on the variables that converged during iteration. The coefficients of the base outcome were then recovered in line with Nmadu et al. (have completely repaid), $\beta_{1}=$ estimated coefficient of those who have repaid part of the loans received $\beta_{2}$ = estimated coefficient of those who are yet to repay. In addition, the partial derivatives or marginal effects and quasi-elasticity of the model were obtained from the software. McFadden's (1974) likelihood ratio index (LRI) also known as pseudo $\mathrm{R}$, similar to the $\mathrm{R}$ in a convectional regression, was computed as $\ln \mathrm{L}=\log$ likelihood function
$\mathrm{nLo}=\log$-likelihood computed with only the constant term.

\section{RESULTS AND DISCUSSIONS \\ Descriptive Statistics Analysis}

The results of the descriptive statistics and analysis are presented in Table 2. The descriptive statistics analysis indicated that majority $(50.56 \%)$ of microcredit farmers were between the age group of 31 40. This is an indication that the bulk of the farmers are within the middle age group, which is in line with the finding of Ngaski et al., (2009) and Tanko et al., (2010). This result has implication for farmer's productivity and loan repayment ability. A total of $65.55 \%$ of the respondents were married while $34.50 \%$ were single. Married persons are known to be more responsible than un-married individuals in the African setting. This also implies that most of the respondents will likely make more responsible farm level decisions which may impact positively on loan repayment. The analysis further revealed that $42.78 \%$ of the respondents owned between 1.1-2.0 hectares of land, which connotes that most of the beneficiaries of agricultural microcredit under Minna Micro Finance Bank are smallholder farmers who will need the Bank's financial support to enhance their means of livelihood. Only, $3 \%$ of the households covered owned above 4 hectares of land. The result also shows that $61.67 \%$ of the respondents do not belong to cooperatives or farmers' associations. This is an indication that most participants may not enjoy the benefits of group cohesion, dynamics, social capital and economic benefits which participants stand to benefit. Household sizes are key determinants of farm level decision making. Majority $(51.67 \%)$ of the respondents had a household size of between 6 and 10 family size, with a mean hundred size of 5 members. The African setting is characterized by large household sizes; while large family sizes could be advantageous in the provision of farm labour. Large family sizes are key determinant of credit repayment. About $67 \%$ of the respondents had secondary education, while a negligible portion $(1 \%)$ was not educated. The level of farmer's education may likely affect the management, utilization and repayment of credit. The matrix further revealed that participation in the crop sub-sector overcrowded the other farming sub-sectors, given that $57.22 \%$ were involved in crop production. The ensuing development is an indication of the weak diversification base of the respondents. 


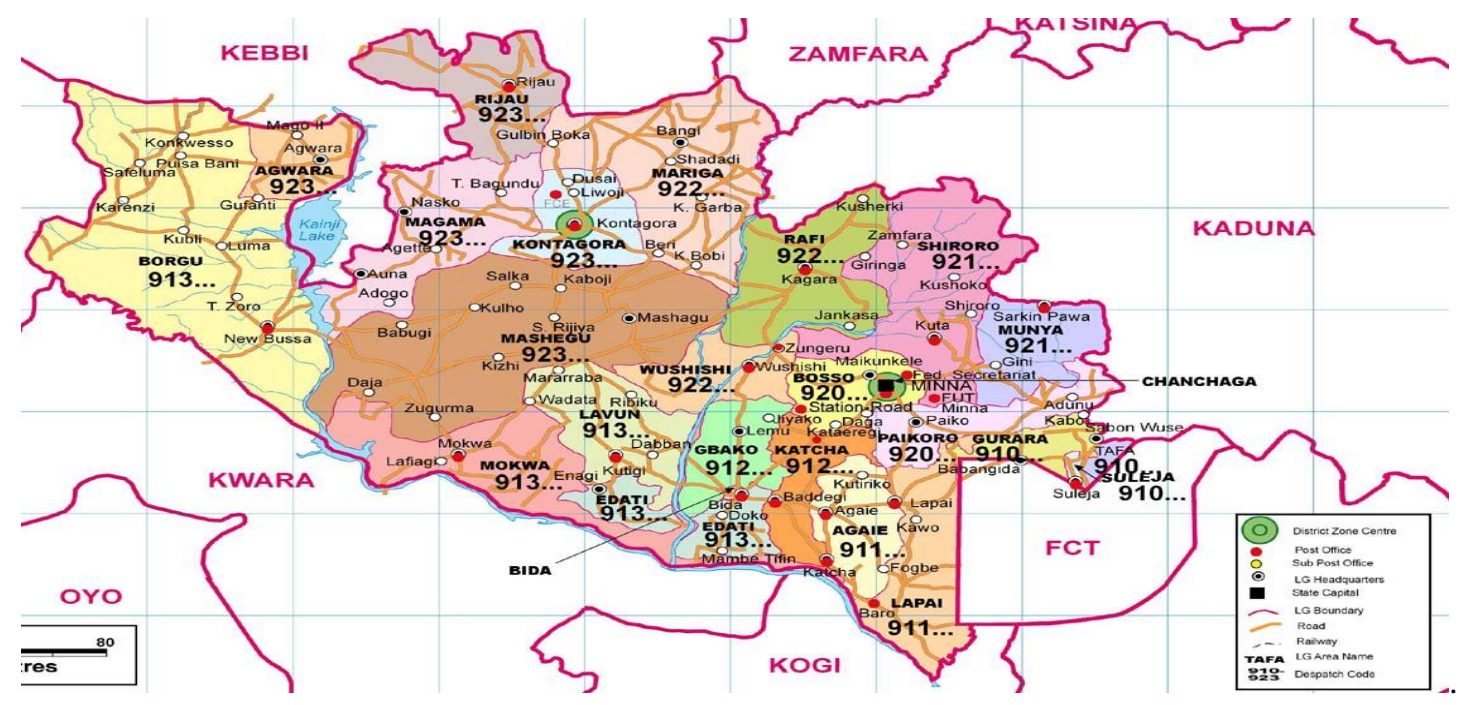

Figure 1: Map of Niger State of Nigeria showing the Study Area (Chanchaga) Source: Open internet window

Table 1.: Sampling Frame of Beneficiaries in Chanchaga LGA

\begin{tabular}{clcc}
\hline S/N & Wards Selected & Beneficiaries Population & Beneficiaries Selected \\
\hline 1. & Limawa A & 200 & 35 \\
2. & Nasarawa A & 150 & 27 \\
3. & Nasarawa C & 100 & 18 \\
4. & Tudun-Wada North & 150 & 27 \\
5. & Minna Central & 100 & 18 \\
6. & Minna South & 300 & 54 \\
\hline & Total & 1000 & 180 \\
\hline
\end{tabular}

Source: Field Survey, 2014

\section{Analysis of Micro-credit Disbursement and Repayment}

The analysis of micro-credit received and repayment showed that $70.56 \%$ of the respondents requested for micro-credit volume ranging from $\$ 50,000$ $\$ 100,000,15 \%$ applied for loan volumes of above $\$ 100,000$ - $\$ 150,000$, while only $1.0 \%$ requested $\$ 250,000$ and above (Table 2). Of the total, 90\% were successful, comprising mainly $62.78 \%$ who received between $\$ 50,000$ and $\$ 100,000$. In terms of repayment, the analysis further revealed that repayment increases with the volume of micro-credit received, as $100 \%$ and $82 \%$ of those who received above $\$ 250,000$ and $\$ 200,000$ - $\$ 250,000$ repaid compared to $74.34 \%$ of those who received between $\$ 50,000$ and $\$ 100,000$. In terms of repayment periods, substantial numbers $(33.89 \%)$ made repayment after six months $21.67 \%$ are yet to pay while $10 \%$ are yet to receive funds. The result is close to the outcome of the study on micro credit repayment among women in Tanzania by Tundui and Tundui (2013) which reported loan repayment difficulties among 19.6 percent of borrowers. The implication of this result is that moat beneficiaries are still limited to small loan volumes which may not be able to entirely cover their enterprise scale. Ironically, the volume of loans disbursed was a factor in micro-credit repayment

\section{Determinants of Micro-credit \\ Repayments among Beneficiaries}

The result from the multinomial logit model (Table 4) indicated that the volume of loans granted was a significant determinant of microcredit repayment among the respondents at $1 \%$ significant level. Other variables in the model like age, sex, household size, farm size, distance, membership of cooperatives, distance from the bank, visits by loan official were found to be insignificant. The result aligns with that of Adegbite (2005); Ajah, Eyo \& Abang (2013); Dayanandan \& Weldeselassie (2009); Dadson (2012) who established that loan volume disbursed was a significant determinant of loan repayment among smallholder farmers. However, the results run contrary to that of by Tundui and Tundui (2013); Ugwumba \& Omojola (2013); Edeth, Atairet, Nkeme, and Udoh (2014) who found no relationship between loan size and loan repayment. The outcome of the study confirms the null hypothesis of this study, given the significance of the loan volume. The result further indicated that as the volume of loan is increased by $\$ 1$, repayment will rise by $\$ 8.4$. This thus suggests that the Minna micro-finance bank should enhance the volume of micro-credit given to beneficiaries relative to the enterprise scale. 
Determinants of Agricultural Micro-Credit Repayment-

Table 2: Results of Descriptive Statistics Analysis

\begin{tabular}{|c|c|c|}
\hline Age in (years) & Frequency & Percentage (\%) \\
\hline 0 & 1 & 0.56 \\
\hline $21-30$ & 32 & 17.78 \\
\hline $31-40$ & 91 & 50.56 \\
\hline $41-50$ & 54 & 30.00 \\
\hline 51 and above & 2 & 1.11 \\
\hline Total & 180 & 100 \\
\hline Gender & Frequency & Percentage (\%) \\
\hline Male & 100 & 55.56 \\
\hline Female & 80 & 44.44 \\
\hline Total & 180 & 100 \\
\hline Marital Status & Frequency & Percentage (\%) \\
\hline Married & 118 & 65.55 \\
\hline Single & 62 & 34.5 \\
\hline Total & 180 & 100 \\
\hline Farm size & Frequency & Percentage (\%) \\
\hline $0.5-1.0$ & 26 & 14.44 \\
\hline $1.1-2.0$ & 77 & 42.78 \\
\hline $2.1-3.0$ & 53 & 29.44 \\
\hline $3.1-4.0$ & 19 & 10.56 \\
\hline 4.1 and above & 5 & 2.78 \\
\hline Total & 180 & 100 \\
\hline Cooperative Membership Status & Frequency & Percentage \\
\hline No & 111 & 61.67 \\
\hline Yes & 69 & 38.33 \\
\hline Total & 180 & 100 \\
\hline Household Size & Frequency & Percentage \\
\hline $1-5$ & 79 & $43.89^{\circ}$ \\
\hline $6-10$ & 93 & 51.67 \\
\hline $11-15$ & 6 & 3.33 \\
\hline $16-20$ & 1 & 0.56 \\
\hline $21 \&$ Above & 1 & 0.56 \\
\hline Total & 180 & 100 \\
\hline Educational Status & Frequency & Percentage \\
\hline None & 2 & 1.11 \\
\hline Adult Education & 13 & 7.22 \\
\hline Primary Education & 14 & 7.78 \\
\hline Secondary Education & 117 & 67 \\
\hline Post Sec. Education & 34 & 18.89 \\
\hline Total & 180 & 100 \\
\hline Enterprise & Frequency. & Percentage (\%) \\
\hline Crop production & 103 & 57.22 \\
\hline Livestock & 31 & 17.22 \\
\hline Fisheries & 30 & 16.17 \\
\hline Mining & 1 & 0.56 \\
\hline Manufacturer & 16 & 8.83 \\
\hline Total & 180 & 100 \\
\hline
\end{tabular}

Source: Field survey, 2014 
Table 3: Details of Micro-credit Requested, Disbursement and Repayment

\begin{tabular}{|c|c|c|c|}
\hline Micro-credit Requested (N) & $\begin{array}{l}\text { Frequency } \\
\text { Percentage }\end{array}$ & $(\%)$ & \\
\hline $50,000-100,000$ & 127 & 70,56 & \\
\hline $100,001-150,000$ & 27 & 15,00 & \\
\hline $150,001-200,000$ & 17 & 9,44 & \\
\hline $200,001-250,000$ & 7 & 3,89 & \\
\hline Above-250,000 & 2 & 1,11 & \\
\hline Total & 180 & 100,00 & \\
\hline Amount of Loan Disbursed (N) & Frequency & Percentage (\%) & \\
\hline Nil & 18 & 10,00 & \\
\hline $50,000-100,000$ & 113 & 62,78 & \\
\hline $100,001-150,000$ & 23 & 12,78 & \\
\hline $150,001-200,000$ & 17 & 9,44 & \\
\hline $200,001-250,000$ & 7 & 3,89 & \\
\hline Above 250,000 & 2 & 1,11 & \\
\hline Total & 180 & 100,00 & \\
\hline Repayment Periods & Frequency & Percentage (\%) & \\
\hline po & 18 & 10,00 & \\
\hline One Month & 3 & 1,67 & \\
\hline Two Months & 21 & 11,67 & \\
\hline Three Months & 20 & 11,11 & \\
\hline Six Months & 61 & 33,89 & \\
\hline Twelve Months & 18 & 10,00 & \\
\hline Yet to Repay & 39 & 21,67 & \\
\hline Total & 180 & 100,00 & \\
\hline $\begin{array}{l}\text { Beneficiaries Repayment ccording } \\
\text { to Loan Volume (Partial/Full) }\end{array}$ & Frequency & $(\%)$ & \\
\hline Nil & 18 & 10,00 & \\
\hline $50,000-100,000$ & 84 & 46,67 & \\
\hline $100,0001-150,000$ & 18 & 10,00 & \\
\hline $150,001-200,000$ & 14 & 7,78 & \\
\hline $200,001-250,000$ & 5 & 2,78 & \\
\hline Above-250,000 & 2 & 1,11 & \\
\hline Yet to Repay & 39 & 21,67 & \\
\hline Total & 180 & 100,00 & \\
\hline Amount of Loans Disbursed & $\begin{array}{c}\text { Beneficiaries Who } \\
\text { Obtained Funds }\end{array}$ & Beneficiaries who repaid (Fully/Partially) & $\begin{array}{c}\% \\
\text { Achiev } \\
\text { ement }\end{array}$ \\
\hline $50,000-100,000$ & 113 & 84 & 74,34 \\
\hline $100,0001-150,000$ & 23 & 18 & 78,26 \\
\hline $150,001-200,000$ & 17 & 14 & 82,35 \\
\hline $200,001-250,000$ & 7 & 5 & 71,43 \\
\hline Above- 250,000 & 2 & 2 & 100,00 \\
\hline Total & 162 & 123 & \\
\hline
\end{tabular}

Source: Field survey, 2014

Table 4: Result of Multinomial Logistic Regression Log Likelihood = 112,294.17 pseudo $R^{2}=0.2214$; No of Observations= 168

\begin{tabular}{|c|c|c|c|c|c|}
\hline Variables & Coefficient. & Std Error & Z score & $P>z$ & $95 \%$ \\
\hline Age & 6.501471 & 0.034069 & 1.47 & 0.141 & 0.11692 \\
\hline Sex & 0.0411738 & 0.2643357 & 0.16 & 0.876 & 0.59926 \\
\hline Household size & 0.0374913 & 0.0625021 & 0.6 & 0.549 & 0.85011 \\
\hline Distance & 0.1385332 & 0.1877161 & 0.74 & 0.461 & 022938 \\
\hline Membership & 0.046658 & 0.5510157 & 0.13 & 0.894 & 0.73464 \\
\hline Loan Granted & 8.456 .06 & 3.987 .06 & $2.12 *$ & 0.034 & 6.468 .07 \\
\hline Visit & 0.0388869 & 0.0858925 & 0.45 & 0.651 & 0.12946 \\
\hline Const & 0.1445725 & 1.345025 & 0.11 & 0.914 & 2.78264 \\
\hline
\end{tabular}

Source: Field Survey, 2014. 
Table 5: Challenges Encountered in Repaying Micro-Credit

\begin{tabular}{lcc}
\hline Variables & Frequency & Percentage(\%) \\
\hline Problem of Guarantor & 74 & 41.11 \\
Loan Application Period & 97 & 53.89 \\
Problem of Collateral & 74 & 41.11 \\
High Interest & 99 & 55.00 \\
Inability to Read \& Write & 54 & 30.00 \\
Short Period of Loan & 124 & 68.89 \\
\hline \multicolumn{1}{c}{ Total } & & $\mathbf{1 0 0}$ \\
\hline Source: Field survey, (2014). & &
\end{tabular}

\section{Challenges to Micro-credit Repayment among Respondents}

Table 5 shows that the distribution of beneficiaries according to the problems faced in repaying micro-credit. The results revealed that majority $(68.89 \%)$ of the respondents indicated that the short period of loan tenor was a major obstacle in loan acquisition, closely following were the high interest rate $(55 \%)$ and loan period $(54 \%)$. The outcome of the result tallies with that of Ugwumba and Omojola (2013) who established that delay in disbursement, high interest rate and excessive bureaucracy were key issues hindering micro-credit repayment.

\section{CONCLUSIONS AND RECOMMENDATIONS}

The study revealed that the volume of credit granted beneficiaries was a significant determinant of agricultural micro-credit repayment in Minna Micro-finance Bank. The interest rate and short period of loan repayment were also key challenges hindering the repayment of micro-credit disbursed by the bank. Based on the outcome of the study, there is the need for proper financial analysis of beneficiaries' enterprise needs with the view to effectively ascertaining the quantum of credit required. This has the two edge advantage of enhancing effective enterprise implementation and allowing for prompt and full loan recovery and or repayment. It has also become imperative to enhance the moratorium of loans being disbursed and fix interest rate based not only on economic but social consideration. A long term option for the bank is to seek long term funds such as the pension contributions from which loan portfolio and operations could be based. Encouraging cooperative participation and channeling microcredits through this institution will enhance effective loan administration, monitoring and recovery.

\section{REFERENCES}

Adegbite, D. A. (2005). Quantitative Analysis of the Major Determinants of Loan Repayment under the Nigerian Agricultural Cooperative Bank Small Holders' Loan Scheme Ogun State, Nigeria. Asset Series A (2005) 5(1):1-12.

Ajah, E.A., Eyo, E. O. and Abang, S.O. (2013). Repayment Performance among Cassava and Yam Farmers under Nigerian Agricultural Bank Smallholder Loan Scheme in Cross River State, Nigeria. British Journal of Economics, Management and Trade 3(4):453-467.

Aku, P. S. (1981). Problems in the Implementation of Agricultural Credit Guarantee Scheme Fund. A Case Study of Selected Credit Institutions in Kaduna State. An Unpublished M.Sc. Thesis, Department of Agricultural Economics, ABU, Zaria, Kaduna.

Awoke, M.U. (2004). Factors Affecting Loan Acquisition and Repayment Pattern of Small-holder Farmers in Ika North East Delta State, Nigeria, J. Sustainable Trop. Agric Res, 9:61-64.

Dadson, A. V. (2012). Determinants of Loan Repayment Default among Farmers in Ghana. Journal of Development and Agricultural Economics. 4 (13) : pp.339345.

Dayanandan, R. and Weldeselassie, H. (2009). Determinants of Loan Repayment Performance among Small Farmers in Northern Ethiopia. Journal of African Development Studies. .2. (1.) :

Edeth, B. N., Atairet, E. A., Nkeme, K.K. and Udoh, E.S (2014). Determinants of Loan Repayment: A study of Rural Women Fish Traders in Akwa-Ibom State, Nigeria. British Journal of Economics, Management and Trade 4(4):541-550, 2014.

Nnanna, O. J., Englama, A. and Odoko, E. O. (2004). Finance, Investment and Growth in Nigeria, Central Bank of Nigeria Corporate Headquarters, Abuja, FCT. 
Ogundele, O. O., Okoruwa, V. O. and Dada, A. D. (2004): "Impact of Non Micro Credit Scheme in Household Welfare in Oyo State. In Ogun Agric. Science 3 (1): 108120.

Olatunji, R. T. (2004). Sources of Credit Facilities among Small Scale Farmers in Ilorin East Local Government Area of Kwara State: Unpublished B. Tech. (Agric.) Project. Department of Agricultural Economics and Extension Technology, Federal University of Technology, Minna.
Ugwumba, C. O. A. and Omojola, I. T. (2013). Determinants of Loan Repayment of Livestock Farmers under Agricultural Credit Guarantee Scheme (A.C.G.S.) in Etche Local Government area of Rivers State, Nigeria. Agricultural Advances. www.sjournals.com

Tundui, C and Tundui, H. (2013). Microcredit, Micro Enterprising and Repayment Myth: The Case of Micro and Small Women Business Entrepreneurs in Tanzania. American Journal of Business and Management. 2 (1) : 20-30. 